\title{
PENERAPAN PENJATUHAN SANKSI PIDANA TERHADAP PELAKU PENCURIAN DOKUMEN ELEKTRONIK MILIK ORANG LAIN DI KOTA MAKASSAR (Studi Putusan No.69/Pid.B/2012/PN.MKS)
}

\author{
Syarif Saddam Rivanie \\ Fakultas Ilmu Sosial Universitas Negeri Makassar \\ Dosen Hukum
}

\begin{abstract}
ABSTRAK
Adanya Undang-Undang Informasi dan Teknologi Elektronik atau yang biasa disingkat dengan UU ITE Nomor 11 Tahun 2008 ini adalah bertujuan untuk menjamin kepastian hukum di bidang informasi dan transaksi elektronik. ITE merupakan payung hukum bagi semua aktivitas dan transaksi di internet dan media elektronik misalnya memindahkan dokumen elektronik milik orang lain. Tujuan penelitian ini adalah untuk mengetahui penerapan hukum pidana materiil oleh hakim terhadap pelaku pemindahan dokumen elektronik milik orang lain putusan No. 69/PID.B/2012/PN.MKS serta untuk mengetahui Pertimbangan Hukum Hakim dalam Menjatuhkan Putusan No. 69/PID.B/2012/PN.MKS. Jenis data yang digunakan oleh penulis dalam proses penyusunan penelitian ini adalah data primer dan data sekunder sedangkan tipe penelitian ini merupakan tipe penelitian empiris dan normative. Sumber data yang penulis peroleh, yaitu melalui hasil wawancara dengan Para Hakim Pengadilan Negeri Makassar yang memutus perkara ini, serta Panitera yang bersangkutan. Data-data yang telah diperoleh baik dari data primer maupun sekunder, kemudian dianalisis secara kualitatif. Selanjutnya data tersebut dituliskan secara deskriptif guna memberikan pemahaman yang jelas dan terarah dari hasil penelitian. Hasil penelitian menunjukan bahwa Penerapan hukum pidana materiil oleh hakim terhadap pelaku pemindahan dokumen elektronik milik orang lain dalam Putusan No.69/PID.B/2012/PN.MKS surat yaitu dakwaan yang disusun oleh penuntut umum telah memenuhi syarat formal dan materiil surat dakwaan sebagaimana dimaksud dalam pasal 143 ayat 2 KUHP. Sedangkan hal-hal yang menjadi pertimbangan hukum oleh majelis hakim dalam menerapkan hukuman terhadap pelaku pemindahan dokumen elektronik milik orang lain dalam putusan No.69/PID.B/2012/PN.M yaitu Perbuatan terdakwa menimbulkan kerugian bagi orang lain dan dapat menghilangkan kepercayaan orang kepada lembaga perbankan serta meresahkan masyarakat
\end{abstract}

Kata Kunci : Sanksi Pidana, Pencurian, Dokumen Elektronik,

\begin{abstract}
The Law on Information and Electronic Technologies or commonly abbreviated as ITE Law No. 11 of 2008 is intended to ensure legal certainty in the field of information and electronic transactions. ITE is a legal umbrella for all activities and transactions on the Internet and electronic media for example, moving an electronic document belonging to someone else. The purpose of this study was to investigate the application of substantive criminal law by judges against the perpetrators of the transfer of electronic documents belonging to others the decision No. 69 / Pid.B / 2012 / PN.MKS and to know Judge Legal Considerations in Decision No. Dropping 69 / Pid.B / 2012 / PN.MKS. The data used by the author in the process of preparation of this study are primary data and secondary data, while this type of research is a type of empirical research and normative. The authors obtained data sources, through interviews with The Makassar District Court judge who is deciding the case, as well as the Registrar concerned. The data have been obtained from both primary and secondary data, and then analyzed qualitatively. Furthermore, the data is written descriptively in order to provide a clear understanding and direction of research. The results showed that the adoption of substantive criminal law by judges against the perpetrators of the transfer of electronic documents belonging to others in Decision 69 / Pid.B / 2012 / PN.MKS letter that the indictments filed by the public prosecutor had qualified formal and material indictment as referred to in article 143 paragraph 2 of the Criminal Code. While things into consideration law by judges in applying penalties against the perpetrators of the transfer of electronic documents belonging to others in decision 69 / Pid.B / 2012 / PN.M that the defendant acts cause harm to others and can eliminate the trust people the banking institutions as well as disturbing the public
\end{abstract}

Keywords: Criminal Sanctions, Theft, Electronic Documents 
ISSN 2528-360X e-ISSN 2621-6159

\section{A. PENDAHULUAN}

Perkembangan dan kemajuan

Tekonologi Informasi yang demikian pesat telah menyebabkan perubahan kegiatan kehidupan manusia dalam berbagai bidang yang secara langsung telah mempengaruhi lahirnya bentukbentuk peraturan hukum yang baru (Undang-Undang no.11 tahun 2008 tentang Informasi dan Transaksi Elektronik, Menimbang Point C)

Transaksi Elektronik dari kartu kredit Indonesia selalu ditolak dalam komunitas E-Commerce dunia sehingga kehilangan potensi pendapatan miliaran dollar AS. Uni Eropa juga telah merekomendasikan untuk tidak melakukan transaksi elektronik ke Negara yang belum memiliki perundangan di bidang teknologi informasi.

Latar belakang adanya UndangUndang Informasi dan Teknologi Elektronik atau yang biasa disingkat dengan UU ITE Nomor 11 Tahun 2008 ini adalah bertujuan untuk menjamin kepastian hukum di bidang informasi dan transaksi elektronik. Jaminan tersebut penting, mengingat perkembangan teknologi informasi telah mengakibatkan perubahanperubahan di bidang ekonomi dan sosial. Perkembangan teknologi informasi telah memudahkan kita mencari dan mengakses informasi dalam dan melalui sistem computer serta membantu kita untuk menyebarluaskan atau melakukan tukar menukar informasi dengan cepat. Jumlah informasi yang tersedia di internet semakin bertambah terus tidak dipenagruhi oleh perbedaan jarak dan waktu.

Menurut M.Arsyad Sanusi (2007:419) materi muatan (substansi) Undang-Undang Informasi dan Transaksi Elektronik yang telah dibentuk di Indonesia adalah materimateri yang mengatur lebih lanjut ketentuan dalam Batang Tubuh UndangUndang Dasar Negara Republik Indonesia Tahun 1945 khususnya pasal 28F Amandemen Keempat UUD Negara Republik Indonesia Tahun 1945 yang berbunyi sebagai berikut :

"Setiap orang berhak untuk berkomunikasi dan memperoleh informasi untuk mengembangkan pribadi dan memperoleh informasi untuk mengembangfkan pribadi dan lingkungan sosialnya, serta berhak untuk mencari, memperoleh memiliki, menyimpan, mengolah, dan menyampaikan informasi dengan menggunakan segala jenis saluran yang tersedia" 
ISSN 2528-360X e-ISSN 2621-6159

Dengan demikian difahami bahwa materi muatan atau subtansi UU Informasi dan Transaksi Elektronik adalah turunan dari ketentuan yang telah digariskan dalam Pasal 28F Amandemen Keempat UUD Negara Republik Indonesia 1945. Sehingga ketentuan-ketentuan yang ada di dalam UU Informasi dan Transaksi Elektronik mencakup ketentuan-ketentuan yang mengatur kegiatan komunikasi dan kegiatan memperoleh informasi, yang meliputi dan menyampaikan informasi dengan menggunakan segala jenis saluran yang tersedia.

UU ITE merupakan payung hukum bagi semua aktivitas dan transaksi di internet dan media elektronik misalnya memindahkan dokumen elektronik milik orang lain. Bahwa aturan ini tertuang dalam pasal 32 ayat 1 UU ITE No.10 tahun 2008, yang berbunyi :

"Setiap orang dengan sengaja dan tanpa hak atau melawan hukum dengan cara apapun mengubah, menambah, mengurangi, melakukan transmisi, merusak, menghilangkan, memindahkan, menyembunyikan suatu informasi elektronik dan/atau Dokumen Elektronik milik orang lain atau milik publik"

Bahwa yang dimaksud dengan hukum siber (cyber law) adalah aspek
Volume 1 No. 1 Desember 2016

hukum yang ruang lingkupnya meliputi setiap aspek yang berhubungan dengan orang perorangan atau subjek hukum yang menggunakan dan memanfaatkan teknologi internet yang dimulai pada saat mulai online dan memasuki dunia cyber atau maya. Cyber law sendiri merupakan istilah yang berasal dari cyberspace law.

Di Indonesia sendiri tampaknya belum ada satu istilah yang disepakati atau paling tidak hanya sekedar terjemahan atas terminology "cyber law". Sampai saat ini ada beberapa istilah yang dimaksudkan sebagai terjemahan dari "cyber law", misalnya, Hukum Sistem Informasi, Hukum Informasi, dan HukumTelematika (Telekomunikasi dan Informatika).

Kegiatan melalui media system elektronik, yang disebut juga ruang siber (cyber space), meskipun bersifat virtual dapat dikategorikan sebagai tindakan atau perbuatah hukum yang nyata. Secara yuridis kegiatan pada ruang siber tidak dapat didekati dengan ukuran dan kualifikasi hukum konvensional saja sebab jika cara ini yang ditempuh akan terlalu banyak kesulitan dan hal yang lolos dari pemberlakuan hukum. Kegiatan dalam ruang siber adalah kegiatan virtual yang 
berdampak sangat nyata meskipun alat buktinya bersifat elektronik.

Berkaitan dengan hal itu, perlu diperhatikan sisi keamanan dan kepastian hukum dalam pemanfataan teknologi informasi, media, dan komunikasi agar dapat berkembang secara optimal. Oleh karena itu, terdapat tiga pendekatan untuk menjaga keamanan di cyber space, yaitu pendekatan aspek hukum, aspek teknologi, aspek sosial, budaya, dan etika. Untuk mengatasi gangguan keamanan dalam penyelenggaraan system secara elektronik, pendekatan hukum bersifat mutlak karena tanpa kepastian hukum, persoalan pemanafaatan teknologi informasi menjadi tidak optimal.(Dikutip dari Penjelasan Umum UU ITE No.10 tahun 2008)

Bahwa semenjak adanya UU ITE ini, telah terjadi kejahatan di Kota Makassar yang melanggar UU ITE no.10 tahun 2008 dengan memperhatikan pasal 48 ayat 1 Jo Pasal 32 ayat (1) Jo. Pasal 55 ayat (1) ke-1 KUHP. Adanya penganjuran dari tersangka utama yang saat ini tersangka utamanya melarikan diri menganjurkan (uitlokker) seorang perempuan yang bernama Lili Heryani untuk turut serta melakukan tindak pidana "Dengan Sengaja dan melawan hukum mentransmisi, memindahkan suatu informasi elektronik / dokumen elektronik milik orang lain berulang kali). Bahwa terdakwa telah dijatuhkan pidana penjara selama : 1 (satu) tahun, 3 (tiga) bulan.

Menurut UU ITE No.10 Tahun 2008, Isi dari pasal 48 ayat 1 adalah "Setiap orang yang memenuhi unsure sebagaimana dimaksud dalam pasal 32 ayat (1) dipidana penjara paling lama 8 (delapan) tahun dan/atau denda paling banyak Rp.2.000.000.000,00 (dua milyar rupiah)

Sedangkan isi dari pasal 32 ayat 1 UU ITE No.11 tahun 2008 adalah "Setiap orang dengan sengaja dan tanpa hak atau melawan hukum dengan cara apapun mengubah, menambah, mengurangi, melakukan transmisi, merusak, menghilangkan, memindahkan, menyembunyikan suatu Informasi Elektronik dan.atau Dokumen Elektronik milik orang lain atau milik public.

\section{B. METODE PENELITIAN}

Lokasi penelitian yang dipilih penulis bertempat di Pengadilan Negeri Makassar. Lokasi penelitian dipilih dengan pertimbangan bahwa Pengadilan Negeritersebut merupakan 
ISSN 2528-360X e-ISSN 2621-6159

tempat diputus

No.69/PID.B/2012/PN.MKS

perkara

yang

merupakan objek sasaran kasus yang diangkat oleh penulis. Jenis data yang digunakan oleh penulis dalam proses penyusunan penelitian ini adalah data primer dan data sekunder.Tipe penelitian ini merupakan tipe penelitian empiris dan normative. Sumber data yang penulis peroleh, yaitu melalui hasil wawancara dengan Para Hakim Pengadilan Negeri Makassar yang memutus perkara ini, serta Panitera yang bersangkutan.Dalam penelitian ini penulis menggunakan teknik pengumpulan data berdasarkan, yaitu : a) Wawancara (interview), dilakukan dengan jalan mengadakan wawancara dengan Hakim Pengadilan Negeri Makassar yang memutus perkara tersebut, atau Panitera yang bersangkutan. b) Penelitian kepustakaan (Library Research), yaitu untuk mengumpulan data-data melalui kepustakaan dengan membaca referensi-referensi hukum, peraturanperaturan perundang-undangan dan dokumen-dokumen dari instansi terkait untuk memperoleh data sekunder.Datadata yang telah diperoleh baik dari data primer maupun sekunder, kemudian dianalisis secara kualitatif. Selanjutnya
Volume 1 No. 1 Desember 2016

data tersebut dituliskan secara deskriptif guna memberikan pemahaman yang jelas dan terarah dari hasil penelitian.

\section{KERANGKA TEORI}

\section{Tindak Pidana}

Menurut Amir Ilyas (2012:19)

Delik yang dalam bahasa Belanda disebut Strafbaarfeit, terdiri atas tiga kata, yaitu straf, baar, dan feit. Yang masing-masing memiliki arti:

- Straf diartikan sebagai pidana dan hukum

- Baar diartikan sebagai dapat dan boleh

- Feit diartikan sebagai tindak, peristiwa, pelanggaran, dan perbuatan..

Jadi istilah Strafbaarfeit adalah peristiwa yang dapat dipidana atau perbuatan yang dapat dipidana.

Menurut Erdianto Effendi, (2011:97-99) istilah tindak pidana adalah terjemahan paling umum untuk istilah strafbaar feit dalam bahasa Belanda walaupun secara resmi tidak ada terjemahan resmi strafbaar feit. Andi Zainal Abidin Farid adalah salah seorang ahli hukum pidana Indonesia yang tidak sepakat dengan 
penerjemahan strafbaar feit menjadi tindak pidana.

Sedangkan menurut Clark dan Marshall (po.cit.:243), bahwa telah merupakan prinsip umum bahwa orang yang berkemampuan bertanggung jawab mengetahui apayang sedang dilakukannya, dan dianggap mempunyai kesengajaan terhadap hasil atau akibat perbuatannya sesuai dengan lazim terjadi atau sesuai dengan kemungkinan terjadinya.

Menurut Moeljatno dalam Erdianto Effendi (2011:98-99), dapat diketahui unsur-unsur tindak pidana sebagai berikut :

1. Perbuatan itu harus merupakan perbuatan manusia

2. Perbuatan itu harus dilarang dan diancam dengan hukuman oleh undang-undang

3. Perbuatan itu bertentangan dengan hukum (melawan hukum)

4. Harus dilakukan oleh seseorang yang dapat dipertanggungjawabkan

5. Perbuatan itu harus dapat dipersalahkan kepada si pembuat.
Menurut rumusan R. Tresna dalam Adami Chazawi (2002:80), tindak pidana terdiri dari unsur-unsur yaitu :

1. Perbuatan / rangkaian perbuatan (manusia)

2. Yang bertentangan dengan peraturan perundang-undangan

3. Diadakan tindakan penghukuman

Sedangkan menurut Vos dalam Adami Chazawi (2002:80), unsureunsur tindak pidana yaitu:

1. Kelakukan manusia;

2. Diancam dengan pidana;

3. Dalam peraturan perundangperundangan

Menurut Jonkers (penganut paham monism) dalam adami Chazawi (2002:81) dapat dirinci unsure-unsur tindak pidana adalah :

a. Perbuatan (yang)

b. Melawan hukum (yang berhubungan dengan);

c. Kesalahan (yang dilakukan oelh orang yang dapat)

d. Dipertanggungjawabk an

2. Locus Delicti dan Tempus Delicti Yurisprudensi mengenal 3 (tiga) macam teori locus delicti, yaitu : 
1. teori perbuatan materiil ; perbuatan madi

2. teori alat

3. teori akibat

a) Teori Perbuatan Materiil

Delicta Commissionis (delik-delik yang diwujudkan dengan berbuat aktif) pada umumnya terjadi di tempat dan waktu pembuat (dader) mewujudkan segala unsure perbuatan dan unsure pertanggungjawaban pidana (criminal liability). Tempat dan waktu terjadinya delictaomissionis (delik yang hanya dapat diwujudkan dengan perbuatan pasif atau tidak berbuat atau berbuat lain daripada yang diperintahkan oleh hukum) terwujud di tempat dan waktu permbuat seharusnya berbuat menurut perintah hukum pidana.

b) Teori Alat

Azenwijse paard-arrest, H.R. pada tanggal 6 April 1915 (N.J.1915, p.427) memutuskan bahwa tempat (locus delicti) terwujudnya delik ialah tempatdimana alat (instrument) bekerja. Hoge Raad di Netherland menganut ajaran tersebut. Di Jerman, teori alat tersebut theorie der langen Hand (hr. : teori tangan panjang) dan di Netherland disebut der leer van her instrument (ajaran tentang alat).

c) Teori Akibat
Menurut Hazenwinkel-Suringa (1973-171) untuk delik-delik materiil, yaitu yang mensyaratkan terwujudnya suatu akibat substansil, teori yang paling cocok digunakan ialaha teori sebab-akibat.

Ajaran tentang de meervoudige locus delicti, yaitu beberapa (lebih dari satu) tempat yang dterima sebagai tempat terwujudnya delik. Dalam hubungan ini perlu diperhatikan pendapat van Hamel (1927:212) yang mengemukakan bahwa harus diterima sebagai locus delicti, adalah :

a. tempat seseorang pembuat (dader) telah melakukan perbuatannya yang dilarang (atau yang diperintahkan) oleh undang-undang pidana

b. tempat alat yang dipergunakan oleh pembuat bekerja;

c. tempat akibat langsung perbuatannya telah terwujud; dan

d. tempat sesuatu akibat konstitutif telah terwujud

3. Bentuk-Bentuk Cybercrime 
ISSN 2528-360X e-ISSN 2621-6159

Menurut Abdul Wahid dan

M.Labib dalam Budi Suhariyanto, (2012:14-16) Sesungguhnya banyak perbedaan diantara para ahli dalam mengklasifikasi kejahatan komputer (computer crime). Ternyata dari klasifikasi tersebut terdapat kesamaan dalam beberapa hal. Untuk memudahkan klasifikasi kejahatan komputer (cyber crime) tersebut, maka dari beberapa klasifikasi dapat disimpulkan:

1. Kejahatan-kejahatan yang menyangkut data atau informasi komputer

2. Kejahatan-kejahatan yang menyangkut program atau software komputer.

3. Pemakaian fasilitasfasilitas komputer tanpa wewenang untuk kepentingankepentingan yang tidak sesuai dengan tujuan pengelolaan atau operasinya

4. Tindakan-tindakan yang mengganggu operasi komputer
Volume 1 No. 1 Desember 2016

5. Tindakan merusak peralatan komputer atau peralatan yang berhubungan dengan komputer atau sarana penunjangnya.

4. Cybercrime di Indonesia

Menurut Budi Suhariyanto (2012:17-18) Peringkat Indonesia dalam kejahatan di dunia maya (menggunakan internet) telah menggantikan posisi Ukraina yang sebelumnya menduduki posisi pertama. Indonesia menempati persentase tertinggi di dunia maya. Data tersebut berasal dari penelitian Verisign, perusahaan yang memberikan pelayanan intelijen di dunia maya yang berpusat di California, Amerika Serikat. Hal ini juga ditegaskan oleh Staf Ahli Kapolri Brigjend Anton Tabah bahwa jumlah cybercime di Indonesia adalah yang tertinggi di dunia. Indikasinya dapat dilihatt dari banyaknya kasus pemalsuan kartu kredit dan pembobobal sejumlah bank.

5. Dokumen Elektronik / Informasi Elektronik

Dikutip dari penjelasan UU ITE No.10 tahun 2008 pasal 1 ayat (4) bahwa Dokumen elektronik adalah setiap informasi yang dibuat, 
diteruskan, dikirimkan, diterima atau

disimpan dalam bentuk analog, digital, elektromagnetik, optikal, atau sejenisnya yang dapat dilihat, ditampilkan dan/atau didengar melalui computer atau sistem elektronik, termasuk tetapi tidak terbatas pada tulisan, suara atau gambar, peta, rancangan, foto, atau sejenisnya, huruf, tanda, angka, kode akses, symbol, atau perforasi yang memiliki makna atau arti atau dapat difahami oleh orang yang mampu memahaminya.

D. PEMBAHASAN HASIL PENELITIAN DAN ANALISIS

1. Penerapan Hukum Pidana Materiil Oleh Hakim Terhadap Pelaku Pemindahan Dokumen Elektronik Milik Orang Lain Putusan

No.

\section{9/PID.B/2012/PN.MKS}

Sebelum penulis menguraikan mengenai penerapan hukum pidana materiil dalam kasus putusan No.69/PID.B/2012/PN.MKS, maka perlu diketahui terlebih dahulu posisi kasus dan penjatuhan putusan oleh majelis hukum dengan melihat acara pemeriksaan biasa pada Pengadilan Negeri Makassar yang memeriksa dan mengadili perkara ini.
Lili Hendrayani bersama-sama dengan Saksi TEO alias AKAP pada hari Minggu tanggal 18 September 2011 dan pada hari JUmat tanggal 23 September 2011 serta pada hari Kamis tanggal 6 Oktober 2011 atau setidak-tidaknya masih dalam bulan September 2011 sampai dengan bulan Oktober Tahun 2011 atau setidak-tidaknya masih dalam tahun 2011 bertempat di Mall Panakkukang tepatnya di Toko Gaudi, Kota Makassar atau setidaknya pada tempat tertentu yang masih termasuk dalam daerah hukum Pengadilan negeri Makassar yang berwenang mengadili, terdakwa dengan sengaja dan tanpa hak melawan hukum dengan cara apapun mengubah, menambah, mengurangi, melakukan transmisi, merusak, menghilangkan, memindahkan, menyembunyikamn suatu informasi elektronik atau dokumen elektronik milik orang lain. Awalnya terdakwa diajak oleh Saksi TEO alias AKAP untuk bekerjasama dalam mengambil data yang terdapat dalam kartu Debit pembeli yang melakukan transaksi di took dimana terdakwa bekerja sebagai supervisor dan atas hal tersebut terdakwa dijanjikan akan diberikan imbalan sebesar Rp.75.000,- (tujuh puluh lima ribu rupiah) untuk kartu 
ATM Silver dan untuk ATM Gold sebesar Rp.100.000,- (seratus ribu rupiah) dan untuk jenis Platinum sebesar Rp.150.000,- (seratus lima puluh ribu rupiah) sedangkan untuk ATM yang lengkap dengan nomor PIN akan diberikan imbalan sebesar Rp.500.000,(lima ratus ribu rupiah);

Bahwa atas ajakan tersebut terdakwa kemudian menyanggupinya dan pada waktu dan tempat sebagaimana tersebut di atas, terdakwa yang merupakan Karyawan Gaudi pada tempat sebagaimana tersebut di atas, menerima beberapa pembeli yang melakukan transaksi dengan cara melakukan pembayaran dengan menggunakan Debit diantaranya saksi emilia basony sarunggallo, saksi viktor tunarso, saksi musdalifa mega lestari yang masing-masing melakukan transaksi dengan menggunakan Kartu Debit Bank Mandiri.

Bahwa setelah menerima kartu dari para saksi tersebut kemudian menggesekannya di Mesin EDC (Electronic Data Capture) untuk kepentingan transaksi dan kemudian kembali menggesekkan kartu tersebut ke mesin skimmer dimana mesin tersebut berfungsi untuk mengambil data-data di kartu ATM milik para saksi selanjutnya data-data elektronik tersebut akan tersimpan di komputer kasirdan oleh terdakwa data tersebut di copy untuk dipindahkan ke Flash Disk selanjutnya data-data tersebut selanjutnya data-data tersebut diserahkan kepada saksi AKAP melalui Email milik saksi AKAP dengan alamat email kasmar1980@yahoo.com atau melalui Pr. nuruna dengan alamat email 198922@yahoo.com atau dikirimkan melalui alamat email istri AKAP dengan alamat email santiken@yahoo.com atau dapat diserahkan juga melalui sms ke nomor HP (handphone) saksi AKAP dan oleh saksi AKAP selanjutnya data tersebut diserahkan kembali kepada Lk. RUSLI dan oleh Lk. RUSLI data-data tersebut dibuatkan Kartu ATM untuk digunakan bertransaksi seolah-olah transaksi tersebut dilakukan oleh para saksi yang kartu ATM nya telah digandakan yaitu dengan cara melakukan penarikan tunai melalui mesin ATM untuk saksi EMYLIA BASO SARUNGALLO pada tanggal 7 Oktober 2011 sebesar Rp.4.000.000,- (empat juta rupiah), tanggal 8 Oktober 2011 sebesar Rp.4.500.000,- (empat juta lima ratus ribu rupiah), dan tanggal 9 Oktober 2011 sebesar Rp.5.000.000,- (lima juta rupiah) dengan total transaksi sebesar 
Rp.13.500.000,- (tiga belas juta lima ratus ribu rupiah) dan untuk saksi MUSDALIFA MEGA LESTARI juga ditarik secara bertahap melalui ATM yaitu pada tanggal 10 Oktober 2011 sebesar Rp.3.500.000,- (tiga juta lima ratus ribu rupiah), dan masih pada hari yang sama sebesar Rp.4.500.000,- (empat juta lima ratus ribu rupiah) dan Rp.5.000.000,(lima juta rupiah) sehingga total transaksi sebesar Rp.13.000.000,- (tiga belas juta rupiah)

Berdasarkan hal tersebut maka dalam dakwaan jaksa tertulis bahwa Pertama : Perbuatan terdakwa sebagaimana diatur dan diancam dengan pidana pasal 48 ayat (1) Jo. Pasal 32 ayat (1) UU Republik Indonesia No.11 Tahun 2008 tentang Informasi dan Transaksi Elektronik Jo. Pasal 65 ayat (1) KUHP Jo. Pasal 55 ayat (1) ke-1 KUHP; Atau Kedua: Perbuatan terdakwa sebagaimana diatur dan diancam pidana pasal 48 ayat (2) Jo. Pasal 32 ayat (2) UU Republik Indonesia No. 11 Tahun 2008 tentang Informasi dan Transaksi Elektronik Jo.Pasal 65 ayat (1) KUHP Jo. Pasal 55 ayat (1) ke-1 KUHP.Atau Ketiga: Perbuatan terdakwa sebagiaman diatur dan diancam pidana pasal 363 ayat (1) ke-4 KUHP :
Tuntutan jaksa Penuntut Umum, Nomor Registrasi Perkara : PDM06/MKS/EP.1/12/2011, yang pada pokoknya meminta kepada Majelis Hakim untuk memutuskan :

a) Menyatakan terdakwa Lili Hendrayani terbukti secara sah dan meyakinkan melakukan tindak pidana "secara tanpa hak memindahkan suatu informasi elektronik dan/atau dokumen elektronik milik orang lain" sebagaimana diatur dan diancam pidana Kesatu : 48 ayat (1) Jo.Pasal 32 ayat (1) UU Republik Indonesia No. 11 Tahun 2008 tentang Informasi dan Transaksi Elektronik Jo. Pasal 65 ayat (1) KUHP Jo. Pasal 55 ayat (1) ke-1 KUHP

b) Menjatuhkan pidana terhadap terdakwa Lili Hendrayani dengan pidana penjara selama 2 (dua) tahun dikurangi selama terdakwa berada dalam tahanan dengan perintah untuk tetap ditahan;

Menurut penulis surat dakwaan yang disusun oleh penuntut umum telah memenuhi syarat formal dan materiil surat dakwaan sebagaimana dimaksud dalam pasal 143 ayat 2 KUHP, yaitu harus memuat tanggal dan ditanda 
tangani oleh penuntut umum serta identitas lengkap terdakwa, selain itu juga harus memuat uraian secara cermat, jelas, dan lengkap mengenai tindak pidana yang didakwakan dengan menyebutkan waktu dan tempat pidana dilakukan. Penyusunan surat dakwaan penuntut umum harus bersifat cermat atau teliti terutama yang berkaitan dengan penerapan peraturan perundang-undangan yang berlaku agar tidak terjadi kekurangan atau kekeliruan yang mengakibatkan batalnya surat dakwaan atau unsureunsur dalam dakwaan tidak berhasil dibuktikan.

Terdakwa dalam kasus ini berdasarkan surat dakwaan penuntut umum, dikenakan pasal 48 ayat (1) jo pasal 32 ayat 1 UU RI Nomor 11 Tahun 2008 tentang Informasi dan Transaksi Elektroniik jo pasal 65 ayat 1 KUHP jo pasal 55 ayat 1 ke- 1 KUHP tersebut maka perbuatan terdakwa haruslah memenuhi unsur-unsur sebagai berikut

1. Unsur Setiap Orang :

Unsur setiap orang adalah yang ditujukan kepada manusia sebagai subjek hukum yang bersifat jasmani dan rohani dan mampu bertanggung jawab / dapat dipertanggung jawabkan secara hukum dan diajukan sebagai rerdakwa ke persidangan

2. Unsur dengan Sengaja :

Bahwa yang dimaksud "dengan sengaja" atau "opzetilijk". Undangundang juga tidak memberikan pengertian pengertian yang jelas tentang maknanya, akan tetapi dalam doktrin hukum pidana diketahui bahwa "dengan sengaja" atau "opzitilijk" haruslah menunjukkan adanya hubungan sikap batin pelaku, baik dengan wujud perbuatannya maupun akibat dari perbuatannya.

Menimbang bahwa hubungan sikap batin pelaku baik dengan wujud perbuatannya maupu dengan akibat perbuatannya dapat dilihat dalam 2 (dua) teori yaitu teori kehendak (wills theorie) yang menitikberatkan kepada apa yang dikehendaki dan teori pengetahuan

(voorstellings theorie), yang menitik beratkan pada apa yang diketahuinya;

Menimbang bahwa dari kedua teori tersebut diatas dapat ditarik suatu tafsiran bahwa "dengan sengaja" atau "opzetilijk" diartikan bahwa menghendaki terjadinya 
perbuatan yang dimaksud dan pelaku sadar atau mengetahui bahwa dari perbuatan yang dikehendakinya itu dapat menimbulkan kerugian bagi orang lain dan hal ini yang lebih mengetahui terdakwa sendiri.

3. Unsur dengan cara apapun mengubah, menambah, mengurangi, melakukan transmisi, merusak menghilangkan, memindahkan, menyembunyikan suatu informasi elektronik dan/atau dokumen elektronik milik orang lain atau milik public. Menimbang bahwa unsure ke-3 tersebut adalah bersifat alternative, artinya cukup salah satu dari rumusan unsure tersebut yang harus dibuktikan.

4. Unsur Melakukan, Menyuruh Melakukan atau Turut Melakukan Menimbang bahwa berdasarkan fakta persidangan sebagaimana telah dipertimbangkan di atas ternyata bahwa terdakwa telah menyuruh Fitriani, Kasir Toko Gaudy yang berada dibawah pengawasannya untuk menggesekannya kartu ATM Customer pada alat skimmer yang telah terdakwa pasang pada komputer kasir toko Gaudy tersebut, kemudian terdakwa melakukan sendiri perbuatan transmisi dan memindahkan datadata kartu ATM milik customer yang telah tersimpan dalam alat skimmer tersebut ke dalam flashdisk dan mengirimkan datanya kepada Irda Firdaus (AKAP) melalui email, dengan menggunakan komputer toko Gaudy termpat terdakwa bekerja. Menimbang bahwa dengan demikian terbukti bahwa terdakwa adalah sebagai orang yang melakukan sendiri atau pelaku yang memindahkan atau mentransmisi data ATM miik orang lain dan menyerahkan kepada orang lain

Menimbang bahwa oleh karena itu maka unsure pasal 55 ayat (1) KUHP telah terbukti dan terpenuhi oleh perbuatan terdakwa.

5. Unsur Perbarengan beberapa perbuatan yangharus dipandang sebagai perbuatan yang berdiri sendiri

Menimbang bahwa yang dimaksud dengan perbarengan disini adalah beberapa perbuatan yang masingmasing dipandang sebagai 
perbuatan

tersendiri-tersendiri yang masing-masing memiliki kejahatan yang terancam dengan hukuman utama yang sejenis.

Menimbang bahwa oleh karena iitu maka menurut Majelis, unsure pasal 65 ayat

1 ke-1 KUHP telah terpenuhi. Mengenai tanggung jawab pidana yang dibebankan kepada terdakwa yang melakukan tindak pidana secara bersama-sama dengan pelaku lain yang bekerja di toko lain, maka terdakwa dibebani tanggung jawab yang sama dengan pelaku lainnya, yakni masingmasing dibebani tanggungjawab yang sama dengan orang lain.

\section{Pertimbangan Hukum Hakim} dalam Menjatuhkan Putusan No. 69/PID.B/2012/PN.MKS

Menimbang, dalam persidangan telah di dengar keterangan saksi-saksi yang memberikan keterangan dengan sumpah masing-masing pada pokoknya sebagai berikut :

a) Saksi Fitriani, pada pokoknya menerangkan sebagai berikut

Bahwa kejadiannya bulan Agustus 2011 atau bulan September 2011. saksi pernah menggesek kartu ATM milik Customer, ke alat skimmer kemudian barulah digesek ke mesin EDC dan saksi tidak pernah meminta no.PIN kepada customer. Kata terdakwa kalau ada customer yang berbelanja pakai ATM, digesek dulu kartunya kea lat skimmer setelah gesek muncul namanya di computer lalu saksi tanyakan kepada customer atas nama ini ya, lalu yang sudah tergesek di alat itu saksi simpan di dalam computer itu karena disuruh oleh terdakwa, kemudian barulah digesek ke mesin EDC dan kata terdakwa nanti terdakwa yang lihat apakah kartu itu maestro atau tidak, karena saksi sebagai kasir takut nantinya saksi nombok sebesar Rp.10.000,-. Bahwa setelah digesek kealat skimmer barulah kartu digesek ke mesin EDC untuk dikeluarkan strok pembayarannya untuk diberikan kepada customer dan mengenai data yang disimpan tadi saksi tidak tahu menahu.Saksi addi wimbandioko asah ; pada pokoknya sebagai berikut. Saksi tahu dengan terdakwa pada saat saksi melakukan investigasi di toko tempat terdakwa bekerja pada bulan Oktober 2011. Saksi mengetahui terdakwa telah melakukan pencurian data karena ada laporan dari 3 orang nasabah dan setelah dicek ternyata ada penggandaan kartu ATM. Bahwa pada saat transaksi 
data dan PIN nya nasabah diperhatikan dan setelah itu terdakwa menyimpan datanya dengan cara kartu digesek 2 kali sedangkan biasanya kartu hanya digesek 1 kali saja, namanya Mesin EDC.Bahwa untuk transaski wajar, kartu digesek ke mesin EDC dan tidak diperlukan mesin skimmer tersebut;

b) Saksi Emylia Basoni Sarungallo

Bahwa yang saksi ketahui tentang terdakwa ini yaitu saksi sebagai korban Debit kartu sebanyak Rp.3.000.000,- pada Bank Mandiri. Bahwa hal itu bisa terjadi karena saksi telah melakukan transaksi pada tanggal 23 September 2011 sekitar jam 09.00 malam di Toko Gaudi Mall Panakkukang. Bahwa kartu ATM saksi terdebet di Surabaya tanggal 7 Oktober 2011 sebesar Rp.3.000.000,- padahal saksi tidak pernah berbelanja di Surabaya.. Bahwa setelah kartu ATM saksi terdebet, saksi mengecek saldonya, uang saksi terdebet Rp.3.000.000,- pada hari Jumat tanggal 7 Oktober 2011, kemudian pada hari Senin saksi buatkan keluhan nasabah di bank Mandiri.

c) Saksi Tri Hidayat

Bahwa saksi bekerja pada toko Planet Surf Kota Makassar selaku kasir sudah 3 tahun.
Adapun poin-poin yang menjadi ratio decidendi dari putusan hakim adalah sebagai berikut Menimbang, bahwa oleh karena selama persidangan tidak ditemukan alasan yang dapat menghapus sifat tindak pidana pada diri Terdakwa baik alasan pembenar maupun alasan pemaaf, maka Terdakwa haruslah dinyatakan bersalah dan dijatuhi pidana yang setimpal dengan kesalahannya tersebut.Menimbang, bahwa oleh karena terdakwa telah dinyatakan bersalah dan bertanggungjawab atas kesalahan melakukan tindak pidana sebagaimana disebutkan di atas dan dijatuhi pidana, maka berdasar pasal 22 KUHAP, terdakwa harus dibebani pula untuk membayar biaya perkara yang besarnya akan disebutkan dalam amar putusan ini.Menimbang, bahwa oleh karena Terdakwa ditahan, maka masa penahananan yang telah dijalani Terdakwa haruslah dikurangkan seluruhnya dari pidana yang dijatuhkan.Menimbang, bahwa pemidanaan bukan merupakan tindakan pembalasan melainkan merupakan pelajaran untuk mendidik agar terdakwa menyadari kesalahannya dan akhirnya terdakwa akan merasa jera dan tidak mengulangi perbuatannya di 
ISSN 2528-360X e-ISSN 2621-6159

masa yang akan datang.Menimbang, bahwa sebelum Majelis Hakim menjatuhkan hukuman terlebih dahulu akan dipertimbangkan hal-hal yang dapat memberatkan dan dapat meringankan Terdakwa guna penerapan pidana yang setimpal dengan perbuatannya tersebut :

a) Hal-hal yang memberatkan :

Perbuatan terdakwa menimbulkan kerugian bagi orang lain dan dapat menghilangkan kepercayaan orang kepada lembaga perbankan serta meresahkan masyarakat.

b) Hal yang meringankan :

1. Terdakwa mengakui terus terang perbuatannya;

2. Terdakwa belum pernah dihukum;

3. Terdakwa masih muda dan masih dapat diharap merubah kelakuannya domasa yang akan datang; Menimbang bahwa oleh karena Terdakwa dinyatakan bersalah maka Terdakwa juga harus dibebani
Volume 1 No. 1 Desember 2016 membayar biaya perkara ini.

Berdasarkan putusan ini hakim dalam putusannya memvonis bahwa terdakwa telah terbukti secara sah dan meyakinkan berslaah melakukan tindak pidana "Dengan sengaja dan melawan hukum mentransmisi, memindahkan suatu informasi elektronik / dokumen elektronik milik orang lain berulang kali" Menjatuhkan pidana kepada Terdakwa oleh karena itu dengan pidana penjara selama 1 (satu) tahun 3 (tiga) bulan;

\section{E. PENUTUP}

Penerapan hukum pidana materiil oleh hakim terhadap pelaku pemindahan dokumen elektronik milik orang lain dalam putusan No.69/PID.B/2012/PN.MKSsurat yaitu dakwaan yang disusun oleh penuntut umum telah memenuhi syarat formal dan materiil surat dakwaan sebagaimana dimaksud dalam pasal 143 ayat 2 KUHP, yaitu harus memuat tanggal dan ditanda tangani oleh penuntut umum serta identitas lengkap terdakwa, selain itu juga harus memuat uraian secara cermat, jelas, dan lengkap mengenai tindak pidana yang didakwakan dengan menyebutkan 
waktu dan tempat pidana dilakukan..

Sedangkan hal-hal yang menjadi pertimbangan hukum oleh majelis hakim dalam menerapkan hukuman terhadap pelaku pemindahan dokumen elektronik milik orang lain dalam putusan No.69/PID.B/2012/PN.M yaitu Perbuatan terdakwa menimbulkan kerugian bagi orang lain dan dapat menghilangkan kepercayaan orang kepada lembaga perbankan serta meresahkan masyarakat

\section{DAFTAR PUSTAKA}

Abdul Wahid dan M. Labib, 2005. Kejahatan Mayantara Cybercrime. Refika Aditama, Bandung.

Adami Chazawi, 2001, Stelsel Pidana, Tindak Pidana, Teori-Teori Pemidanaan dan Batas Berlakunya Hukum PIdana: Pelajaran Hukum Pidana. Rajawali Press. Jakarta.

Amir Ilyas, 2012, Asas-Asas Hukum

Pidana I : Memahami Tindak

Pidana dan Pertanggungjawaban Pidana sebagai Syarat Pemidanaan. Rangkang Education dan PuKAP Indonesia. Yogyakarta.

Amir Ilyas, 2012, Asas-Asas Hukum

Pidana II. Rangkang Education dan PuKAP Indonesia. Yogyakarta.

Andi Zainal Abidin Farid, 2007. Hukum

Pidana 1. Sinar Grafika. Jakarta.
Budi Suhariyanto, 2012, Tindak Pidana Teknologi Informasi (Cybercrime): Urgensi Pengaturan dan Celah Hukumnya. Rajawali Press. Jakarta.

Erdianto Effendi, 2011, Hukum Pidana Indonesia: Suatu Pengantar, PT. Refika Aditama, Bandung.

E.Y.Kanter dan R.Sianturi, 1982, Asas Hukum Pidana di Indonesia dan Penerapannya. Alumni AHMPTHM. Jakarta.

Lilil Mulyadi,2007. Hukum Acara Pidana, Normatif, Teoritis, Praktik, dan Permasalahannya. Alumni. Bandung.

M.Arsyad Sanusi, 2007. Konvergensi Hukum dan Teknologi Informasi (Sebuah Torehan Empiris-Yuridis). Indonesia Rearch. Jakarta.

Moeljatno, 1983. Perbuatan Pidana dan Pertanggungjawaban dalam

Hukum Pidana. Bina Aksara, Jakarta.

Mustafa Abdullah dan Ruben Achmad. 1989. Intisari Hukum Pidana. Ghaka Indonesia. Jakarta.

P.A.F.Lamintang, 1997. Dasar-Dasar Hukum Pidana Indonesia. Citra Aditya Bakti. Bandung.

S.R.Sianturi, 1986. Asas-Asas Hukum

Pidana di Indonesia dan 
ISSN 2528-360X

e-ISSN 2621-6159

Penerapannya. Alumni Ahaem,

Petehaem. Jakarta. 